\title{
АРХЕОЛОГИЯ
}

Ш.О. Давудов

\author{
АРХЕОЛОГИЧЕСКИЕ НАХОДКИ ИЗ ОКРЕСТНОСТЕЙ С. АЛМАК \\ (Публикация подготовлена при финансовой поддержке \\ Фонда содействия отечественной науке)
}

В апреле 2006 г. в отдел археологии Института истории археологии и этнографии поступили некоторые предметы, происходившие из окрестностей с. Алмак Казбековского района РД. Они были переданы жителем этого селения А. Сатыраевым. С его же помощью в окрестностях с. Алмак автором был осмотрен могильник, из которого происходила часть этих предметов ${ }^{1}$. Могильник находится в урочище Гайли, на правой террасе р. Акташ, в 5 км севернее с. Алмак. На территории могильника были видны полуразрушенные каменные ящики, сложенные из тонких плит песчаника. Погребения ориентированы по линии запад - восток с отклонением к северу или югу.

Все переданные нам предметы относятся к албано-сарматскому времени и происходят с ограниченной территории. Таким образом, они объединены только этими обстоятельствами, и выявить их комплексные связи невозможно.

Ниже дано их описание.

\section{Орудия труда}

1. Однолезвийные железные ножи со слабо выгнутой спинкой (2 экз.). Длина сохранившейся части лезвия одного из них - 5,5 см, ширина колеблется в пределах - 1,6-1 см (Рис. 1, 3). Длина сохранившейся части лезвия второго ножа 4,2 см, ширина в пределах - 1,3-1 см (Рис. 1, 4).

2. Однолезвийный железный прямой нож (1 экз.). Длина сохранившейся части лезвия этого ножа - 5,8 см, ширина в пределах 1,9-1,3 см (Рис. 1, 6).

3. Железный прямой нож с заостренным концом и отверстием для крепления рукоятки в основании черешка. Длина сохранившейся части лезвия - 7,1 см, ширина - 1,4-0,8 см, длина обломка черенка - 0,6 см (Рис. 1, б).

\section{Керамика}

1. Миниатюрная миска-плошка усеченно-конической формы с прямыми стенками и четырьмя выступами-шишечками, расположенными вдоль края венчика на равном расстоянии (один выступ не сохранился). Диаметр венчика 10 см, диаметр дна - 7 см, высота - 3,5 см. Тесто серо-коричневато-охристое с примесью шамота, поверхность заглаженная, светло-коричневато-бежевого цвета (Рис. 1, 1).

2. Фрагмент плоского дна и нижней части тулова столового гончарного сосуда. Диаметр дна - 10,7 см. Тесто серо-коричневое с примесью шамота. Поверхность заглаженная, светло-коричневого цвета.

\section{Предметы вооружения}

1. Навершие меча из меловой породы, представляющее собой полусферу с плоским основанием. Поверхность изделия покрыта радиально расходящимися из

\footnotetext{
${ }^{1}$ Автор выражает благодарность А. Сатыраеву за помощь, оказанную при сборе материалов для данной статьи.
} 
центра процарапанными линиями, образующими мелкие валики. Основание изделия гладкое. Диаметр - 4,6х4,3 (разница из-за искажения формы) см, диаметр отверстия - 0,5 см, толщина - 3,3 см (Рис. 1, 2).

Аналогичные навершия характерны для сарматских позднесарматских памятников. Особенно часто они встречаются на Боспоре (Хазанов А.М., 1971. С. 16). Одно такое навершие из горного халцедона было обнаружено на Сумбатлинском могильнике (Давудов О.М., 1971).

2. Железный втульчатый наконечник дротика с узким листовидным пером. Перо едва выделяется от линии втулки. Длина сохранившейся части пера - 9,1 см, втулки - 7,1 см. Диаметр втулки - 1,1 см (Рис. 1, 7).

3. Миниатюрный железный трехлопастный черешковый наконечник стрелы. Общая длина наконечника 2,2 см при длине сохранившейся части черешка - 0,7 см и длине головки $-1,5$ см (Рис. 1,8 ).

Этот наконечник аналогичен мелким экземплярам трехлопастных наконечников сарматского облика, распространенным на Северном Кавказе в I IV вв. н.э. (Давудов О.М., 1996. С. 129) Миниатюрные наконечники исчезают у сарматов во II в. в связи с распространением больших луков (Мошкова М.Г., 1989. C. 184-185).

\section{Украшения и предметы туалета}

1. Браслеты (5 экз. целые, 1 - фрагментированный) представлены несколькими типами.

a) Браслеты из круглой в сечении проволоки, концы которых привязаны друг к другу спиральными оборотами концов. Из них 4 бронзовых, 1- серебряный. Из 4 бронзовых браслетов один представлен невыразительными обломками. Два браслета свернуты из гладкой круглой в сечении проволоки. Размеры одного из этих браслетов 6,9х6,5 см, диаметр сечения проволоки, из которой сделан браслет, - 2-3 мм. Тонкие, свернутые в спирали концы этого изделия сломаны и сохранились в виде нанизанных на браслет колечек и коротких спиралей (Рис. 2, 6). Размеры второго браслета - 6,8х6,7 см, диаметр сечения проволоки - 2,5-3 мм (Рис. 2, 10). Последний бронзовый браслет изготовлен из круглой в сечении витой проволоки. Размеры украшения - 6х6,5 см. Диаметр сечения проволоки - 2-3 мм (Рис. 2, 4). Серебряный браслет из гладкой круглой в сечении проволоки. Состоит из трех фрагментов. Его свернутые в спирали концы частично обломаны. Размеры изделия - 6,2х7, диаметр сечения проволоки - 2-3 мм (Рис. 2, 7).

В Дагестане такие браслеты были встречены на Цархигоцинском, Карабудахкентском, Хабадинском и Новолакском могильниках (Давудов О.M., 1996. С. 147). В Северном Причерноморье, а также в Грузии и на Северном Кавказе этот тип украшений появляется со II - I вв. до н.э. (Куфтин Б.А., 1950. Т. II. C. 55. Табл. 18; Ломтатидзе Г.А., 1957. Табл. ХIX, 15; Уварова П.С., 1900. Т. VIII. Табл. XXII, 10; Анфимов Н.В., 1951. С. 196. Рис. 17, 15; Абрамова М.П., 1978. С. 27. Рис. 7, 32; Висотская Т.Н., 1972. С. 155; Корпусова В.А., 1983. С. 59. Рис. $16,12)$. Встречаются они также на памятниках Центральной Европы и Балкан первых веков нашей эры (Зубарь В.М., 1982. С. 94. Рис. 61, 1 - 7) где, возможно, находился центр их производства (Висоикая Т.Н., 1972. С. 155).

б) Бронзовый браслет из овальной в сечении проволоки с заходящими концами (в 1,5 оборота). Размеры украшения - 8x7,9 см, диаметр сечения проволоки - 3х4,5 мм. Концы браслета ровно обрезаны (Рис. 2, 2).

Такие браслеты встречаются в Дагестане еще на памятниках каякентско-харачоевской культуры (Марковин В.И., 1994. С. 347), а в албано-сарматское время - в погребениях Хабадинского, Карабудахкентского I, Мамрашского, Урцекского могильников и Большого Буйнакского кургана. Встречены они и на раннесредневековых памятниках. За пределами Дагестана этот тип украшений 
был распространен на территории Северного Кавказа, Закавказья и Крыма (Давудов О.М., 1996. С. 147).

в) Бронзовый браслет из круглой, гладкой проволоки с разомкнутыми, приостренными, заходящими концами. Размеры - 6,1х6,6 см, диаметр сечения проволоки - 2 мм (Рис. 2, 9).

г) Бронзовый браслет из круглой в сечении проволоки с ровно обрезанными разомкнутыми концами (размеры $-7,2 \times 6,6$ см, диаметр сечения проволоки $-4 \times 3$ мм) (Рис. 2, 8).

Браслеты этого типа также распространены с каякентско-харачоевского времени (Марковин В.И., 1966, С. 62-64.). Найдены они и на таких памятниках Дагестана албанского времени, как Таркинский, Карабудахкентский I, Мамрашский, Урцекский могильники, Большой Буйнакский курган и др. (Давудов O.M., 1996. С. 147). Эти украшения продолжали встречаться и в раннесредневековое время (Атаев Д.М., 1963. С. 142. Рис. 18, 2; Маммаев М.М., 1969. С. 198).

2. Бронзовые круглые подвески в полтора оборота (2 экз.).

a) Подвеска из тонкой уплощенной проволоки в 1,5 оборота. Концы подвески плотно прилегают друг к другу. Размеры подвески - 1,4x1,3 см, сечение проволоки - 1,2х0,8 мм (Рис. 3, 5)

б) Подвеска в 1,5 оборота из круглой в сечении относительно толстой проволоки с расходящимися заостренными концами. Высота изделия $-0,8$ см, общие размеры - 1,4х1,3 см, диаметр сечения проволоки - 2-2,5 мм (Рис. 3, б).

Такие подвески наиболее характерны для памятников каякентско-харачоевской культуры (Марковин В.И., 1969. С. 65-66). Появились они в Дагестане в кон. III тыс. до н.э. и исчезают только в раннем средневековье (Марковин В.И., 1966. С. 65-66: Рис. 28, 5-7; Котович В.Г., 1982. С. 59, 60. Рис. 8, 51-65). А. Б. Куфтин связывал их появление на Кавказе с влиянием Месопотамии (Куфтин А.Б., 1941. С. 94. Рис. 96). В Месопотамии в III тыс. до н.э. эти украшения встречаются во многих разновидностях (царские гробницы Ура) (Wolley C.L., 1934. Pl. 14, 17813; 219, 10735; Чайлд Г., 1956. Табл. XXV, 8569, 8613).

3. Бронзовые подвески в форме кольца с несомкнутыми расходящимися в виде буквы V концами (2 экз.). Одна из них свернута из овальной в сечении, неравномерно прокованной проволоки. Общая длина изделия $-2,4$ см, диаметр кольца - 0,8 см, длина концов - 0,9 см, диаметр сечения проволоки - 2х1 мм (Рис. $3,3)$. Вторая подвеска свернута из утолщающейся на концах проволоки. Общая длина изделия - 3,4 см, диаметр кольца - 1,3 см, длина концов 1,9-1,8 см, диаметр сечения проволоки в центральной части подвески - 1х2 мм, а на концах -3 мм (Рис. 3, 2).

Подобные украшения возникли в Дагестане в сер. I тыс. до н.э. и продолжали встречаться здесь в течение всего албано-сарматского периода (Давудов О.М., 1996. С. 148). Производились они, вероятно, в Дагестане и отсюда в процессе торгово-экономических контактов проникали в довольно отдаленные районы (Чечня, Нижнее Поволжье) (Синицын И.В., 1960. С. 34. Рис. 11, 13; 21).

4. Бронзовая подвеска (кольцо?), свернутая из относительно толстой пластины, резко сужающейся в месте спайки концов. Диаметр кольца - 1,2 см, сечение пластины - от 1,5х0,7 мм до $6 \times 3$ мм (Рис. 3, 4).

5. Коническая подвеска, свернутая из бронзовой пластины. В верхнем, заостренном конце имеется отверстие для подвешивания размером 0,4х0,3 см. Высота подвески - 2,3 см. Толщина пластины, из которой свернуто изделие, $-0,2$ мм. Размеры основания конуса - 1,1х0,9 см (Рис. 3, 10).

Наиболее ранняя подвеска такой формы происходит из коллекции Н.В. Орла, которая была собрана при обследовании погребений в окрестностях чеченского с. 
Ведено (Круглов А.П., 1946. С. 69. Рис. 16, 12). Такие подвески встречаются на территории Дагестана в скифское и албанское время (Давудов О.М., 1996. Рис. 29, 41, 42; 56, 6; 63, 8, 16; 67, 17). За пределами Дагестана неизвестны.

6. Подвески-колокольчики из бронзы (3 экз.).

a) Литая подвеска, представляющая собой два соединенных в нижней части колокольчика с ажурными треугольными прорезями в два ряда и ушками для подвешивания. Колокольчики имеют форму конуса со слегка выпуклыми стенками. Высота - 2,7 см, диаметр основания каждого из сдвоенных колокольчиков равен в среднем 1,5 см. Толщина стенок - 10-15 мм (Рис. 3, 8).

Аналогов такой сдвоенной подвески не известно. Хотя одинарные колокольчики-подвески с ажурными прорезями встречаются в древностях Дагестана достаточно часто. Эти украшения были наиболее широко распространены в албано-сарматское время и в раннем средневековье (Маммаев M.M., 1969. С. 202, 203).

б) Литая подвеска-колокольчик в форме конуса с тремя треугольными прорезями и ушком для подвешивания в верхней части. Высота $-1,8$ см, размеры ушка - 0,6х0,2 см. Основание подвески овальное размером 1х0,7см (Рис. 3, 9).

Эта подвеска относится к тому же типу, что и описанная выше подвескаколокольчик.

в) Полусферический колпачок или колокольчик, изготовленный из бронзового листа толщиной 1-0,8 мм. Высота изделия - 1,1 см, диаметр основания - 1,8 cм. В центре полусферической подвески закреплен обломанный железный штырь подпрямоугольного сечения (3х1,5 мм) длиной 1 см, вероятно, остатки язычка колокольчика (Рис. 3,1$)$.

Подобные подвески появляются в Дагестане в эпоху поздней бронзы и продолжают встречаться вплоть до средневековья. Наиболее популярны эти украшения в албано-сарматское время и в раннем средневековье.

7. Бронзовые элементы поясного набора:

Четыре круглорамчатые пряжки. Три из них скреплены со скобами, в основании которых есть отверстие для штыря, с помощью которого пряжка крепилась к кожаному ремню. Все пряжки имеют круглый в сечении, заостренный на конце язычок. Их размеры: 2,1х1,6 см, диаметр сечения рамки 2,5 мм (Рис. 4, 8); 2х2,3, длина скобы - 3,7 см, ширина - 1,5 см, диаметр сечения рамки - 3 мм (Рис. 4, 9); 2х2,6 см, длина скобы - 4,6 см, ширина - 1,4-1,6 см диаметр сечения рамки - 3 мм (Рис. 4, 7); 2,8х2,6 см, длина скобы - 2,2 см, ширина - 2,2 см, диаметр сечения рамки - 4 мм (Рис. 4,10$)$.

Шесть наконечников ремней, представляющих собой узкие прямоугольные пластины. Они различаются по методу прикрепления к ремню. Два наконечника крепились к ремню с помощью штыря, продетого в отверстие на одном из концов пластины. Один такой наконечник представлен маленьким обломком с отверстием на конце (Рис. 4, 2), второй сохранился полностью (его размеры: длина - 6,6 см, ширина - 1,6-1,4 см) (Рис. 4, 3). Три наконечника состоят из двух частей - узкой пластины с прямоугольным отверстием на одном из концов и продетой через это отверстие скобы. Скоба закреплялась на ремне с помощью штыря. Два изделия сохранились полностью. Их размеры: длина пластины - 6 см, ширина - 1,3 см, длина скобы - 3 см, ширина - 1,1 см (Рис. 4,1$)$; длина пластины - 4,2 см, ширина - 1 см, длина скобы - 1,9 см, ширина - 1 см (Рис. 4, 6). Один наконечник сохранился частично (размеры: длина сохранившейся части пластины - 3 см, ширина - 1 см, длина скобы - 2,1 см, ширина - 2,4 см) (Рис. 4, 4).

Круглорамчатые пряжки были широко распространены в Дагестане в албаносарматское время (Давудов О.M., 1996. С. 145). Они появляются на памятниках Северного Кавказа в I - III вв. н.э. и наиболее широкое распространение получают 
во II - V вв. Встречаются они и в более позднее время (Абрамова М.П., 1978. С. $117,118,132)$.

Рассматриваемые пряжки имеют близкие аналогии среди позднесарматских бронзовых пряжек, относящихся ко II - первой половине III в. (Максименко B.E., Безуглов С.И., 1987. С. 190. Рис. 4, 9, 10). Наконечники ремней довольно многочисленны в сарматских погребениях первой половины III в. на Нижней Волге (Толстой И., Кондаков Н., 1889. С. 31 - 33. Рис. 25; Raи P., 1927 б. С. 31-33) и в степном Подонье (Мошкова М.Г., Максименко В.E., 1974. Табл. XVI; 27. С. 113). Учитывая имеющиеся аналогии, данные наконечники ремней могут быть датированы II -III вв. н.э. (Толстой И., Кондаков Н., 1889. С. 156. Рис. 138; Ломтатидзе Г.А., 1955. С. 70-72; 1957. Рис. на С. 473; Максименко В.Е., Безуглов С.И., 1987. С. 190. Рис. 2. 18-20; 4, 14, 15).

8. Бронзовая пряжка-сюльгама, язычок отсутствует (размеры пряжки $3,1 \times 2,5$ см, сечение - 2,5 мм) (Рис. 2, 5).

Такие пряжки характерны для памятников Дагестана I - V вв. н.э. Сюльгамы продолжают встречаться вплоть до XII в. (Маммаев М.M., 1969. С. 208; Ломтатидзе Г.А., 1957. С. 219-222).

9. Железная скоба, скрепленная штырем. Сохранились остатки деревянной основы, к которой крепилась скоба.

10. Фибулы из низкопробного серебра, бронзы, железа (12 целых и 12 обломков). Представлены различными типами.

a) Лучковые подвязанные проволочные бронзовые, одночленные фибулы (2 целые и 4 фрагмента). Одна фибула сохранилась полностью (длина - 6,3 см, высота спинки - 3 см) (Рис. 3, 20). У второй фибулы поврежден приемник (длина - 7,5 см, высота спинки - 3,3 см) (Рис. 3, 21). Остальные четыре фрагмента невыразительны, хотя легко определяются как обломки данного типа фибул.

В Дагестане основная масса таких находок относится ко II-III вв. н.э. (Давудов О.М., 1996. С. 152).

б) Шарнирные фибулы раннеримских типов из бронзы (4 экз.) и серебра (1 экз.). Спинки фибул из описываемой коллекции имеют различные формы, что вообще характерно для этого типа фибул.

Бронзовая с железной иглой фибула, спинка которой имеет вид простого уплощенного с задней стороны стержня, изогнутого под тупым углом (длина $-4,5$ см, высота спинки - 1,9 см) (Рис. 3, 13).

Бронзовая с железной иглой фибула с такой же спинкой, украшенной в месте перегиба двумя треугольными насечками (длина $-2,2$ см, высота спинки $-0,8$ см) (Рис. 3, 16).

Бронзовая с железной иглой фибула со спинкой в виде уплощенного с задней стороны стержня, украшенного плоским ромбическим щитком. Также спинка фибулы, от ножки до щитка украшена тонкими косыми гравированными линиями (длина - 6,2 см, высота спинки - 1,8 см) (Рис. 3, 22).

Бронзовая фибула с круглой пластинчатой спинкой (длина - 2, см, высота спинки 0,9 см) (Рис. 3, 17).

Серебряная фибула с железной иглой со спинкой, изогнутой под тупым углом и представляющей собой гладкий треугольный щиток (длина - 3,9 см, высота спинки - 1,2 см) (Рис. 3, 11).

Фибулы этого типа были распространены в I в. до н.э. - I в. н.э. (Амброз А.К., 1966. С. 26-27). Среди описанных фибул выделяется одна - с круглой спинкой и выступом на конце ножки. Аналогичные фибулы были встречены только на территории Дагестана в комплексах II - III вв. (Амброз А.К., 1966. С. 27. Табл. 4, 24).

в) Сильно профилированные фибулы причерноморских типов с бусиной на 
головке и крючком для тетивы (3 целые, 2 фрагмента) из бронзы и железа.

Железная фибула со спинкой в виде круглого, изогнутого под тупым углом стержня с двумя бусинами у головки и приемника (вариант I-2 по А. К. Амброзу) (длина - 5,3 см, высота спинки - 1,4 см) (Рис. 3, 19).

Бронзовая фибула с пластинчатой дугообразно изогнутой овально-вытянутой спинкой (вариант I-3 по А.К. Амброзу) (длина - 5,6 см, высота спинки - 1,4 см) (Рис. 3, 23).

Бронзовая фибула с пластинчатой овально-вытянутой спинкой (вариант I-3 по А.К. Амброзу). Фибула искривлена, головка и приемник частично обломаны (длина - 5,3 см) (Рис. 3, 14).

Фибулы, относящиеся к варианту I-2, А.К. Амброз датирует II в. н.э., а фибулы, относящиеся к варианту I-3 датирует II - первой половиной III вв. (Амброз А.К., 1966. С. 40-41. Табл. 8, 7, 8, 10, 11).

г) Миниатюрная бронзовая пружинная фибула со спиральным завитком на конце пластинчатого приемника и с пластинчатой, дугообразно изогнутой спинкой (длина - 3,2 см, высота спинки - 1,3 см) (Рис. 3, 18).

Такие фибулы датируются I - II вв. н.э. (Амброз А.К., 1966. С. 45. Табл. 5, 15, 16).

д) Серебряная шарнирная провинциальная римская фибула, украшенная цветной эмалью. Игла сломана. Щиток прямой, в виде двух соединенных вершинами треугольников с круговыми выступами в месте соединения и в основании одного из них. Поверхность щитка заполнена эмалью рыжеватокрасного цвета с круглыми вставками черного и голубого цвета. Круговые выступы заполнены светло-зеленой с голубыми вставками эмалью. В верхней части спинка под прямым углом соединяется с шарниром и образует площадку, украшенную гравированным орнаментом в виде ряда из пяти концентрических кругов (длина фибулы - 3,9 см) (Рис. 3, 15).

Римские фибулы, украшенные эмалью, датируются в основном II в. н.э. В начале III в. н.э. вывоз эмалевых фибул из римских провинций прекратился (Амброз А.К., 1966. С. 29-30. Табл. 14, 3-16).

11. Бронзовые подвески в виде фигурок собак (одна целая, вторая фрагментированная).

Подвески представляют собой скульптурное изображение собаки. Одна подвеска более реалистично изображает собаку с острыми ушами и загнутым хвостом и отверстием для подвешивания в боку фигурки (размеры: высота - 2,5 см, длина - 3 см) (Рис. 3, 7). Вторая подвеска представляет собой фигурку, выполненную в такой же манере, но более схематично. Туловище плоское, ноги и хвост обломаны (размеры: высота сохранившейся части $-1,9$ см, длина $-2,4$ см) (Рис. 3, 12).

Эти украшения являются отражением почитания этого животного. Во многих могильниках Дагестана албанского времени зафиксированы ритуальные захоронения собак (Смирнов К.Ф., 1961. С. 183; Кудрявцев А.А., 1985. С. 139). Согласно данным этнографии, собака в представлениях кавказских народов связана с потусторонним миром мертвых и духов (Салихов Б. М., 1997. С. 42; Скаков А.Ю., 1998. С.20). Захоронение или принесение в жертву собаки во время похорон человека, вероятно, имело целью оградить покойного от злых духов во время его путешествия в «страну мертвых» (Бакушев М.A., 2006. С. 25-26).

12. Зеркала из низкопробного серебра (биллон). Два зеркала сохранились полностью, третье представлено невыразительным обломком.

a) Зеркало диаметром 5,5 см с боковым ушком с отверстием, валиком по краю и коническим утолщением в центре (Рис. 2, 1).

Зеркала подобного типа довольно широко представлены на памятниках 
Дагестана албано-сарматского времени. Наиболее ранним из них является зеркало из погребения №5 Карабудахкентского I могильника, датируемое I в. до н.э. - I в. н.э. (Смирнов К.Ф., 1961. С. 207. Рис. 5, 95). Другие зеркала рассматриваемого типа найдены в Таркинском (Крупнов Е.И., 1951. Рис. 8, 6; Смирнов К.Ф., 1951. С. 260. Рис. 17, 2), Сумбатлинском (Давудов О.М., 1970. С. 120, 121. Табл. IV, 1, 11; V, 10), Урцекском (Маммаев М.М., 1969. С. 214 - 216. Рис. 9, 8) и Андрейаульском (Абрамова М.П., Магомедов М.Г., 1980. С. 127, 128. Рис. 2, 9; 3, 16) могильниках. Как правило, они лишены орнамента.

Зеркала с боковым ушком с отверстием, валиком по краю и коническим утолщением в центре были широко распространены в I - II вв. н.э. на Северном Кавказе, и в различных регионах Евразии (Хазанов А.М., 1963. С. 64; Литвинский Б.A., 1978. С. 68 и сл.). Вопрос об их генезисе окончательно не решен, хотя по этому вопросу имеется немало исследований (Rau P., 1927a. S. 90 - 96; Книпович T.Н., 1949. С. 55 - 59; Хазанов А.М.,. 1963. С. 65 - 70; Абрамова М.П., 1971. С. 121 - 132; Виноградов В.Б., Петренко В.А., 1976. С. 44 - 49).

б) Зеркало диаметром 3,5 см с боковым ушком с отверстием, украшено орнаментальной композицией, состоящей из двух вписанных, друг в друга кругов, соединенных между собой радиально расходящимися линиями. В центральной части зеркала, обрамленной описанными кругами, расположена фигура в виде квадрата с вытянутыми и закругленными углами. В центре зеркала находится небольшой конический выступ (Рис. 2, 3).

Данное зеркало также относится к описанному выше типу зеркал-подвесок. Орнамент на обороте таких зеркал появляется только со II в. Н.э. (Виноградов В.Б., Петренко B.A., 1976. С. 48) Знак в виде квадрата изображен на зеркалах из Сумбатлинского и Урцекского могильников (Давудов О.М., 1996. С. 153. Рис. 51, $8,10)$, а также на зеркалах, происходящих из других регионов Северо-Восточного Кавказа (Крупнов Е. И., 1941. С. 183 - 185; Виноградов В.Б., 1963. С. 202. Рис. 27) и на памятниках из Поволжья (Синицын И.В., 1978. С. 52. Рис. 18, б).

Знак в виде квадрата, вписанного в круг, или круга, вписанного в квадрат, является одним из широко распространенных символов. Такая фигура - один из основных сакральных символов буддийской мифологии (мандала). Он представляет собой, в частности, схему устройства вселенной (Неклюдов С.Ю., 1997. С. $100-102)$.

Таким образом, можно полагать, что данное зеркало носит культовый характер. Зеркала были одним из важных атрибутов, применявшихся савроматскими жрицами в религиозных церемониях (Мошкова М.Г., 1989. С. 188). Маленькие зеркала-подвески могли играть роль амулетов (Литвинский Б.А., 1964). В конце II в. н.э. зеркала-подвески исчезают (Давудов О.М., 1996. С. 153).

в) Невыразительный обломок зеркала с двумя концентрическими валикам по краю.

В представленной коллекции довольно значительное место занимают разнообразные по форме и материалу бусы. Среди них можно выделить несколько типов.

13. Бусы из так называемого египетского фаянса. В античное время производились, вероятно, в Египте (Алексеева E.M., 1975. С. 27-28). Различные мелкие украшения из египетского фаянса на рубеже эр широко импортировались из Египта в Северное Причерноморье, откуда могли распространяться на Северный Кавказ и в другие районы (Пиотровский Б.Б., 1958. С. 20-28; 1931. С. 28-30).

a) Круглые ребристые бусы бирюзового цвета из египетского фаянса (2 экз.). Бусы сформованы из плотной мелкозернистой массы без стекловидного покрытия. Одна бусина сохранила первоначальный вид (Рис. 5, 2), вторая 
обточена с четырех сторон, что придало ей форму близкую к кубу (вероятно более соответствовавшую вкусам населения Дагестана) (рис. 5, 1).

Е.М. Алексеева относит такие бусы к типу 16а своей классификации и датирует их основную массу II в. до н.э. - II в. н.э. (Алексеева E.M., 1975. С. 36. Табл. 5, 26, 36).

б) Подвески из египетского фаянса бирюзового цвета в виде стилизованных амфорок с перетяжкой около дна, каннелированным туловом, валиком и ушком для подвешивания в верхней части (2 экз.) (тип 82 по Е.М. Алексеевой) (Рис. 5, 3, 4). Сформованы из плотной мелкозернистой массы без стекловидного покрытия.

В Северном Причерноморье датируются I - IV вв. н.э., но наибольшее распространение приходится на I - II вв. н.э. (Алексеева E.M., 1975. С. 46. Табл. 11, 42-44).

в) Подвески из египетского фаянса бирюзового цвета в виде гениталий (2 экз.) (тип 90 по Е.М. Алексеевой). Моделирована одна сторона подвесок, сзади они плоские (Рис. 5, 5, 6).

В Северном Причерноморье датируются концом I в. до н.э. - II в. н.э. (Алексеева Е.M., 1975. С. 47. Табл. 7, 28-30; 12, 22).

14. Бусы из многоцветного стекла (23 экз.):

a) Бусина округлой формы из непрозрачного темно-синего стекла, украшенная слоистыми глазками. Центральный диск из глухого сероватого стекла окружают кольца белого и красного цвета (Рис. 5, 7).

б) Поперечно-сжатые, округлые бусы из глухого сероватого стекла (вероятно, в древности имело желтоватый оттенок) с синими, почти смыкающимися глазками; центр синего цвета окружен чередующимися белыми и сероватыми кольцами (5 экз.) (тип 68 по Е.М. Алексеевой) (Рис. 5, 8-12).

Датируются I в. до н.э. - I в. н.э. (Алексеева E.M., 1975. С. 67. Табл. 14, 2123).

в) Округлая бусина из глухого темно-синего стекла, украшенная глазками, состоящими из синего диска, окруженного кольцом белого стекла (тип 78а по Е.М. Алексеевой) (Рис. 5, 16).

В Северном Причерноморье встречаются в комплексах V в. до н.э. - II н.э. (Алексеева Е.M., 1975. С. 68. Табл. 15, 8-11).

г) Округлые бусины из глухого красного стекла (2 экз.). Одна украшена пятнышками глухого стекла желтого цвета (Рис. 5, 15), вторая сильно коррозирована, пятна не сохранились (Рис. 5, 14).

Вероятно, относятся к типу 46 по Е.М. Алексеевой. Единственный датированный комплекс с такими бусами относится ко второй половине IV в. н.э. (Алексеева Е.М., 1975. С. 57. Табл. 12, 48).

д) Округлая поперечно-сжатая бусина из глухого стекла темно-синего цвета, украшенная продольной волнистой линией из глухого белого стекла (Рис. 5, 13).

е) Круглая бусина из полупрозрачного бесцветного стекла (Рис. 5, 18).

ж) Цилиндрической формы ребристая бусина из прозрачного светлого стекла серовато-зеленоватого цвета (Рис. 5, 24).

3) Подвеска усеченно-грушевидной формы из прозрачного бесцветного стекла (Рис. 5, 17).

и) Круглая бусина из матового стекла синего цвета (Рис. 5, 21).

к) Круглая бусина из прозрачного синего стекла со следами пятнышек, вероятно, из белого или желтого глухого стекла (Рис. 5, 22).

л) Цилиндрическая бусина из глухого стекла. Основа в настоящее время черная. На нее нанесен орнамент полосами глухого стекла бирюзового цвета. Основания бусины обведены полосами глухого красновато-коричневого стекла (Рис. 5, 23). 
м) Бочковидная бусина из глухого, в настоящее время черного стекла, покрытая орнаментом в виде поперечных волнистых полос глухого белого стекла (Рис. 5, 19).

н) Цилиндрическая бусина из двухслойного стекла. Основа - желтое глухое стекло, верхний слой - прозрачное зеленое. Бусина украшена тонкими поперечными пересекающимися полосами глухого белого стекла и круглыми вставками с выдавленными на них рельефными розетками (цветы) из такого же стекла. Выемки розеток, изображающие лепестки и центр цветка, заполнены черной стеклянной массой (Рис. 5, 20).

о) Крупная округлая бусина, украшенная т.н. ковровым орнаментом. Орнамент образован квадратиками глухого стекла черного, белого, красного, зеленого и желтого цвета (Рис. 5, 25).

Бусы с ковровым узором характерны для I - II вв. н.э., но продолжали изготавливаться и в III - IV вв. н.э. (Алексеева Е.M., 1975. С. 35).

15. Бусы из полудрагоценных камней (20 экз.).

a) Крупная бусина из красноватого, слабо просвечивающего сердолика. Форма бусины овально-уплощенная, в сечении близка к ромбу. Отверстие для нанизывания имеет равный диаметр, выполнено путем двустороннего сверления (Рис. 6, 1).

б) Небольшая круглая бусина из красноватого с желтоватым оттенком полупрозрачного сердолика. Отверстие для нанизывания узкое, с одной стороны отверстия имеется кратеровидная воронка, образовавшаяся в результате просверливания отверстия (Рис. 6, 3).

в) Округло-цилиндрическая бусина из полупрозрачного сердолика равномерного розоватого цвета (Рис. 6,4$)$.

г) Цилиндрическая бусина из красноватого с желтоватым оттенком слабо просвечивающего сердолика. По технике изготовления может быть отнесена к т.н. рубленному типу. Отверстие для нанизывания с одной стороны немного шире (Рис. 6, 2).

д) Округлые бусы (7 экз.) из молочного или дымчатого халцедона различных оттенков: от почти прозрачного до мутно-желтоватого. Отверстие для нанизывания узкое, с одной стороны шире, чем с другой. Почти на всех бусинах у широкого конца отверстия имеется уплощенная площадка, небольшая воронка или насечка, отмечавшие место начала сверления отверстия (Рис. 6, 6-12).

е) Упрощенно-округлая бусина из слабо просвечивающего сероватого дымчатого халцедона. Отверстие для нанизывания широкое, имеет равный диаметр. Сверление одностороннее, со стороны выхода сверла края отверстия рваные, сколотые (Рис. 6, 5).

Бусы из дымчатого халцедона характерны для албано-сарматского времени и раннего средневековья. В предшествующее время в Дагестане не встречаются.

ж) Бусины из янтаря 1 целая (Рис. 6, 13) и три фрагмента (Рис. 6, 14-16). Целая бусина имеет округлую форму с узким отверстием. Фрагменты принадлежат удлиненным бусинам. В сечении они имеют овальную, уплощенную с одной стороны форму.

3) Коралловые темно-красные удлиненные цилиндрические пронизи. Видна слоистая структура материала (Рис. 6, 18).

В Северном Причерноморье аналогичные коралловые бусы встречаются в комплексах римского времени (Алексеева E.M., 1975. С. 30. Табл. 43, 29).

и) Бусина из черного гагата (гишира). Бусина имеет гантелевидную форму. В центре бусины - поперечное отверстие (Рис. 6, 17).

Аналогичные бусы были найдены в погребении 12 Зеленоморского кургана кладбища, датируемого рубежом эр (Салихов Б.М., 1987. С. 18. Рис. 24, 7). 
16. Крупные бусы уплощенно-округлой формы из меловой породы (2 экз.) (Рис. 6, 20, 21).

17. Бусина, отлитая из низкопробного серебра (1 экз.). Имеет форму, близкую к кубу, со сглаженными углами и гранями (Рис. 6, 19).

\section{БИБЛИОГРАФИЯ}

Абрамова М.П., 1971. Зеркала горных районов Северного Кавказа в первые века нашей эры // История и культура восточной Европы по археологическим данным. М.

Абрамова М.П., 1972. Нижне-Джулатский могильник. Нальчик.

Абрамова М.П., 1978. Большой Буйнакский курган // Археологические памятники раннесредневекового Дагестана: Материалы по археологии Дагестана. Т. 7. Махачкала.

Абрамова М.П., Магомедов М.Г., $1980 . \quad$ О происхождении культуры Андрейаульского городища // Северный Кавказ в древности и средние века. М.

Алексеева E.M., 1975. Античные бусы Северного Причерноморья // Археология

СССР. Свод археологических источников. Вып. Г1-12. М.

Амброз А.К., 1966. Фибулы юга европейской части СССР // Археология СССР. Свод археологических источников. Вып. Д1-30. М.

Анфимов Н.B., 1951. Меото-сарматский могильник у станицы Усть-Лабинской // МИА. № 23. М.

Атаев Д.М., 1963. Нагорный Дагестан в раннем средневековье. Махачкала.

Бакушев М.А., 2006. Погребальный обряд населения Дагестана албано-сарматского времени (III до н.э. - IV в. н.э). Автореф. канд. дис. Махачкала.

Виноградов В.Б., 1963. Сарматы Северо-Восточного Кавказа // Тр. ЧНИИ. VI. Грозный.

Виноградов В.Б., Петренко В.А., 1976. Происхождение сарматских зеркал-подвесок Северного Кавказа // КСИА. Вып. 148. М.

Висотская Т.Н., 1972. Поздние скифы в Юго-Западном Крыму. Киев.

Давудов О.М., 1971. Сумбатлинский могильник - памятник материальной культуры

Дагестана албано-сарматского и раннесредневекового времени // ТД. посвященные итогам полевых археологических исследований в 1970 г. в СССР. Тбилиси.

Давудов О.М., 1996. Материальная культура Дагестана албанского времени (III в. до н.э. - IV в. н.э). Махачкала.

Зубарь В.М., 1982. Некрополь Херсонеса Таврического I - IV вв. н.э. Киев.

Книпович Т.Н., 1949. Танаис. Историко-археологическое исследование. М.-Л.

Корпусова В.А., 1983. Некрополь Золотое. Киев.

Котович В.Г., 1982. Проблемы культурно-исторического и хозяйственного развития населения древнего Дагестана. М.

Котович В.Г., Мунчаев Р.М., Путинцева Н.Д., 1961. Некоторые данные о средневековых памятниках горного Дагестана // МАД. Т. 2. Махачкала.

Круглов А.П., 1946. Северо-Восточный Кавказ во II - I тысячелетиях до н.э.: Тез. канд. дисс. // КСИИМК. Вып. 5. М.

Крупнов Е. И., 1941. Археологические памятники Ассинского ущелья // Тр. ГИМ АС. Вып. XII. M.

Крупнов Е.И., 1951. Новый памятник древних культур Дагестана: Опыт первого исследования Таркинского могильника 1947 г. // МИА. № 23. М.

Кудрявиев А.А., 1985. Дербентский могильник // Древние культуры СевероВосточного Кавказа. Махачкала.

Куфтин А.Б., 1941. Археологические раскопки в Триалети. М.

Куфтин Б.А., 1950. Материалы по археологии Колхиды. Тбилиси.

Литвинский Б.А., 1964. Зеркало в верованиях древних ферганцев // СЭ. № 3. М.

Литвинский Б.А., 1978. Орудия труда и утварь из могильников западной Ферганы. М.

Ломтатидзе Г.А., 1955. Археологические раскопки в древнегрузинской столице

Мцхета. Тбилиси.

Ломтатидзе Г.А., 1957. Некрополь II в. в Клдеете. Тбилиси.

Максименко В.Е., Безуглов С.И., 1987. Позднесарматские погребения в курганах на 
реке Быстрой // СА. № 1.

Маммаев М.М., 1969. К характеристике металлообрабатывающего ремесла Урцекского городища албано-сарматского и раннесредневекового времени // УЗ. ИИЯЛ Дагфил. АН СССР. Т. 19. Вып. 2. Махачкала.

Маммаев М.М., 1970. Зооморфные пряжки Урцекского могильника // СА. № 4.

Марковин В.И., 1966. Дагестан и горная Чечня в древности. Каякентскохорочоевская культура. М.

Марковин В.И., 1994. Каякентско-харачоевская культура // Археология. Эпоха бронзы Кавказа и Средней Азии. Ранняя и средняя бронза Кавказа. М.

Мошкова М.Г., 1989. Среднесарматская культура // Археология СССР. Степи европейской части СССР в скифо-сарматское время. М.

Неклюдов С.Ю., 1997. Мандала // Мифы народов мира. Т. 2. М.

Пиотровский Б.Б., 1931. Египетские предметы в Северо-Кавказском крае // СГАИМК. №6. М.

Пиотровский Б.Б., 1958. Древнеегипетские предметы найденные на территории Советского Союза // СА. №1.

Салихов Б.М., 1987. Отчет отряда дагестанской экспедиции ИА РАН СССР о раскопках Зеленоморского кургана в 1986 году // РФ ИИАЭ ДНЦ РАН. Ф. 3. Оп. 3. Д. 679.

Салихов Б. М., 1997. К вопросу о культе собаки в Дагестане // Материалы конференции, посвященной 100-летию со дня рождения Т. М. Минаевой. Ставрополь.

Синицын И.В., 1960. Древние памятники в низовьях Еруслана (по раскопкам 19541955 гг.) // МИА. № 78.

Синищын И.В., 1978. Древние памятники Восточного Маныча. Саратов.

Скаков А.Ю., 1998. Об одной из групп кобано-колхидских орнаментированных топоров // Историко-археологический альманах. Армавир.

Смирнов К.Ф., 1951. Археологические исследования в районе дагестанского сел. Тарки в 1948-1949 гг. // МИА. № 23.

Смирнов К.Ф., 1961. Грунтовые могильники албано-сарматского времени у сел. Карабудахкент // Материалы по археологии Дагестана. Т. 2. Махачкала.

Уварова П.С., 1900. Могильники Северного Кавказа // МАК. Т. VIII. М.

Хазанов А.М., 1963. Генезис сарматских бронзовых зеркал // СА. № 4.

Хазанов А.М., 1971. Очерки военного дела сарматов. М.

Чайлд Г., 1956. Древнейший Восток в свете новейших исследований. М.

Rau P., 1927a. Hugelgraber romischer Zeit an der unteren Wolga (Ergebnisse der Graberforschung in der Wolgadeutscen Republik). Pokrowsk.

Rau P., 1927б. Prähistoriche Ausgrabungen auf der Steppenseit des Deushen Wolgagebiets im Jahre 1926. Pokrowsk.

Wolley C.L., 1934. Ur excavations. Vol II. The royal Cemetery. Ney Iork. 


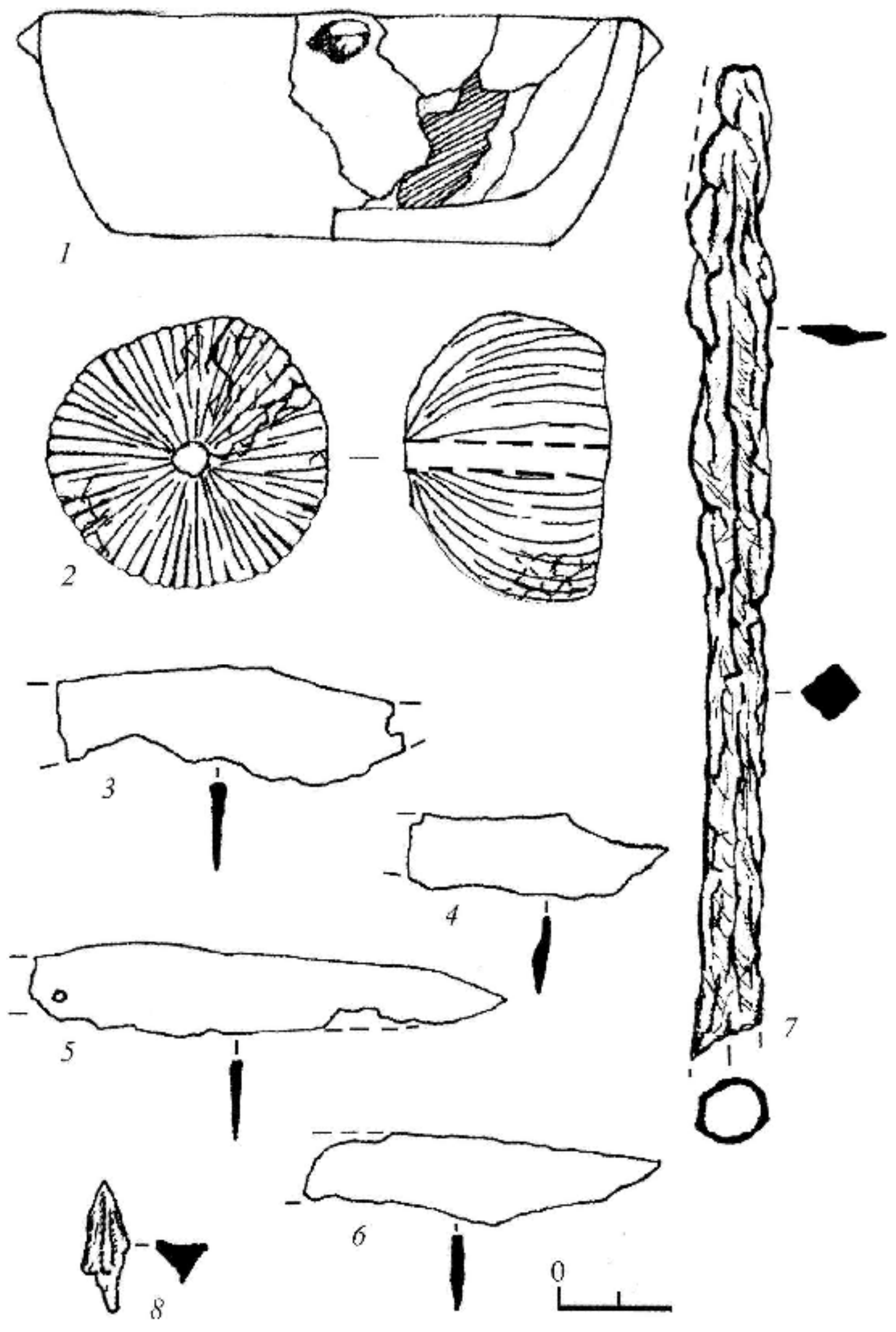

Рис. 1. Находки из окрестностей с. Алмак.

Керамика, орудия труда и предметы вооружения 


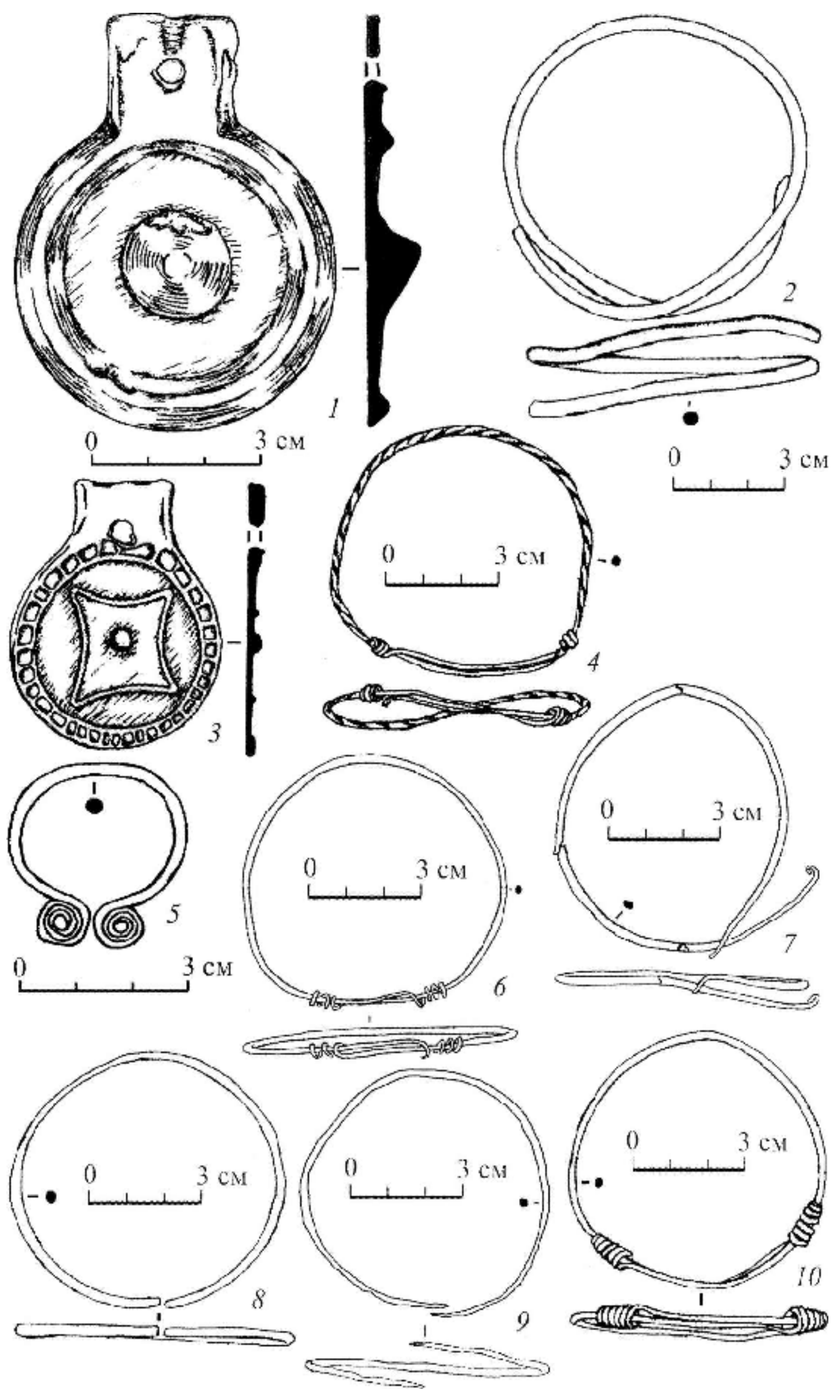

Рис. 2. Находки из окрестностей с. Алмак.

Зеркала, браслеты, сюльгама 


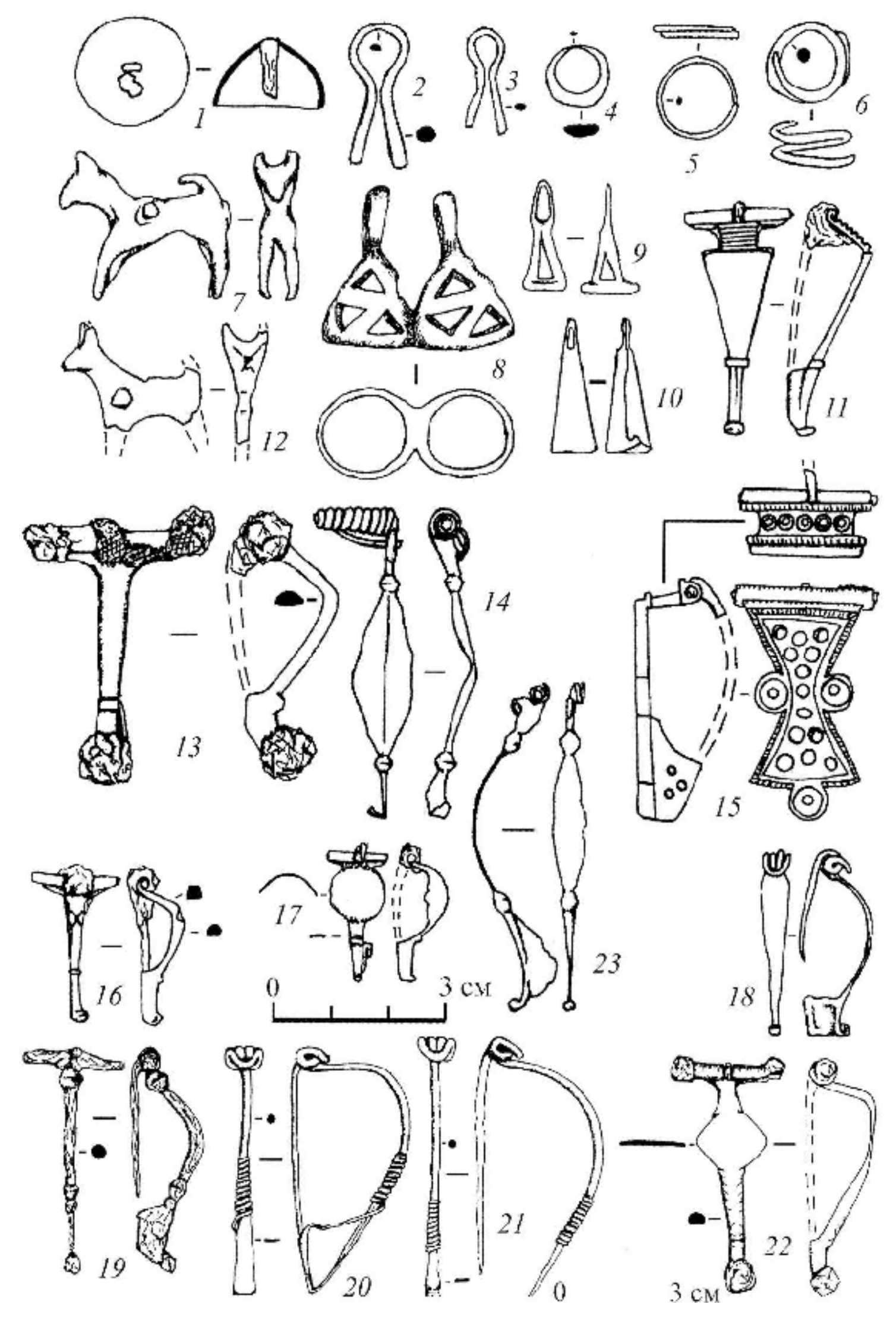

Рис. 3. Находки из окрестностей с. Алмак.

Подвески, фибулы 


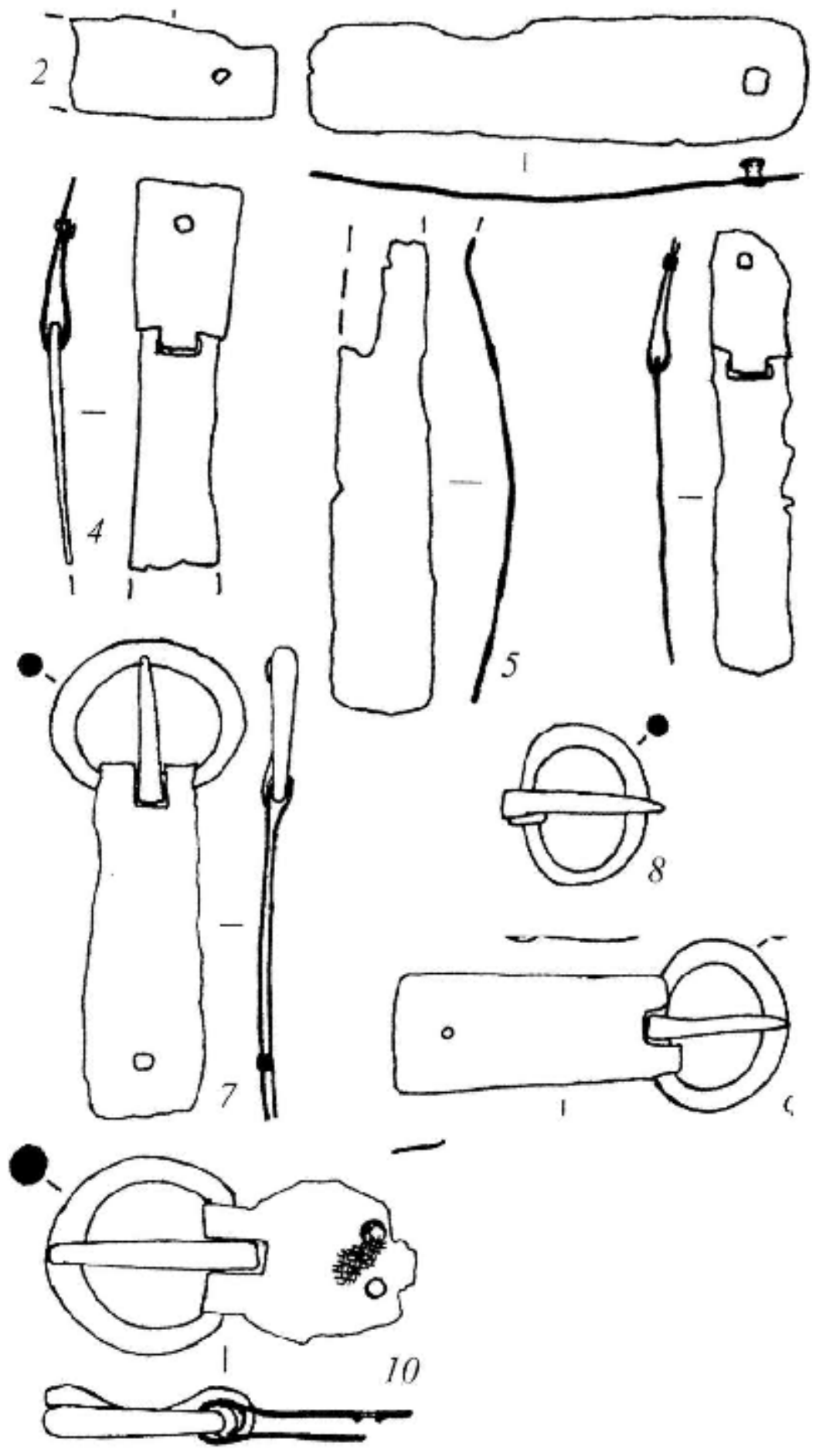

Рис. 4. Находки из окрестностей с. Алмак. Элементы поясного набора 


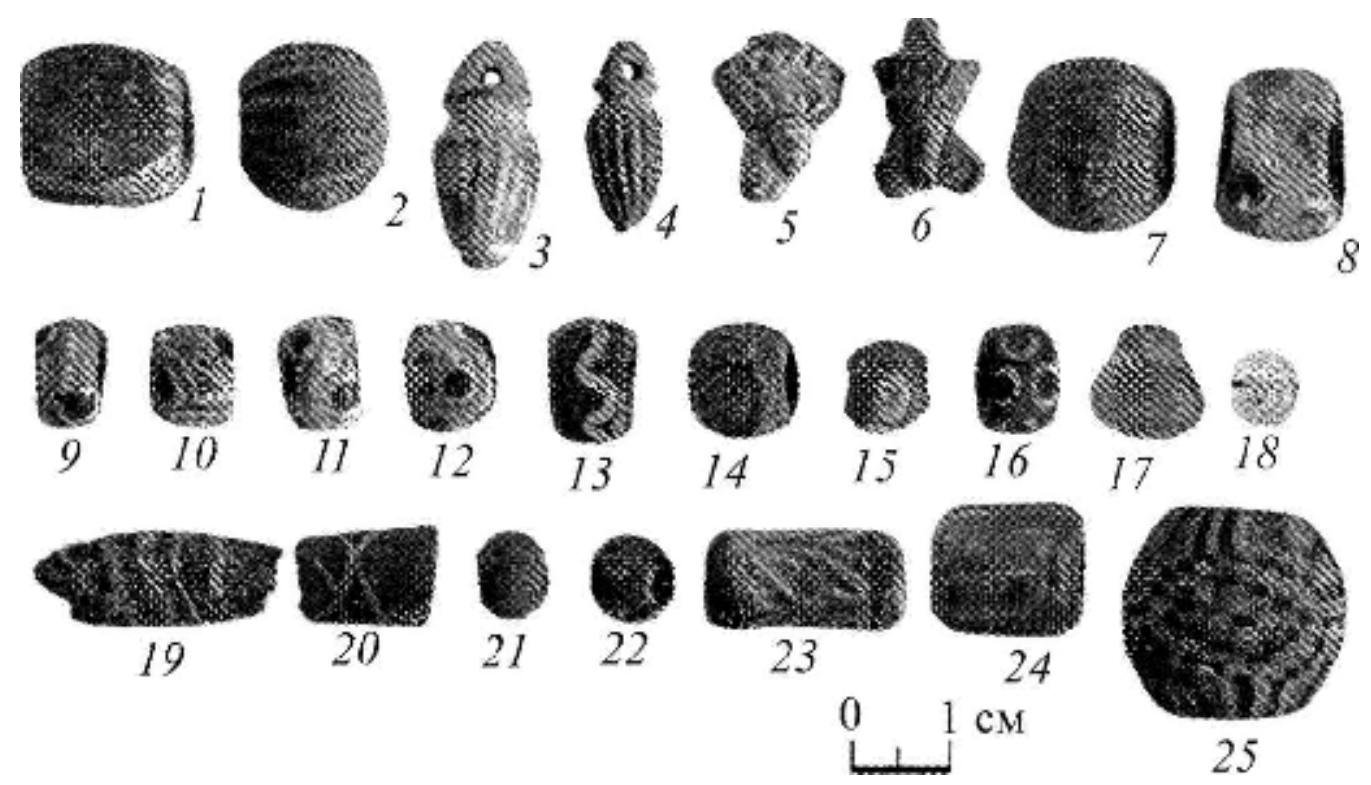

Рис. 5. Находки из окрестностей с. Алмак. Бусы из многоцветного стекла
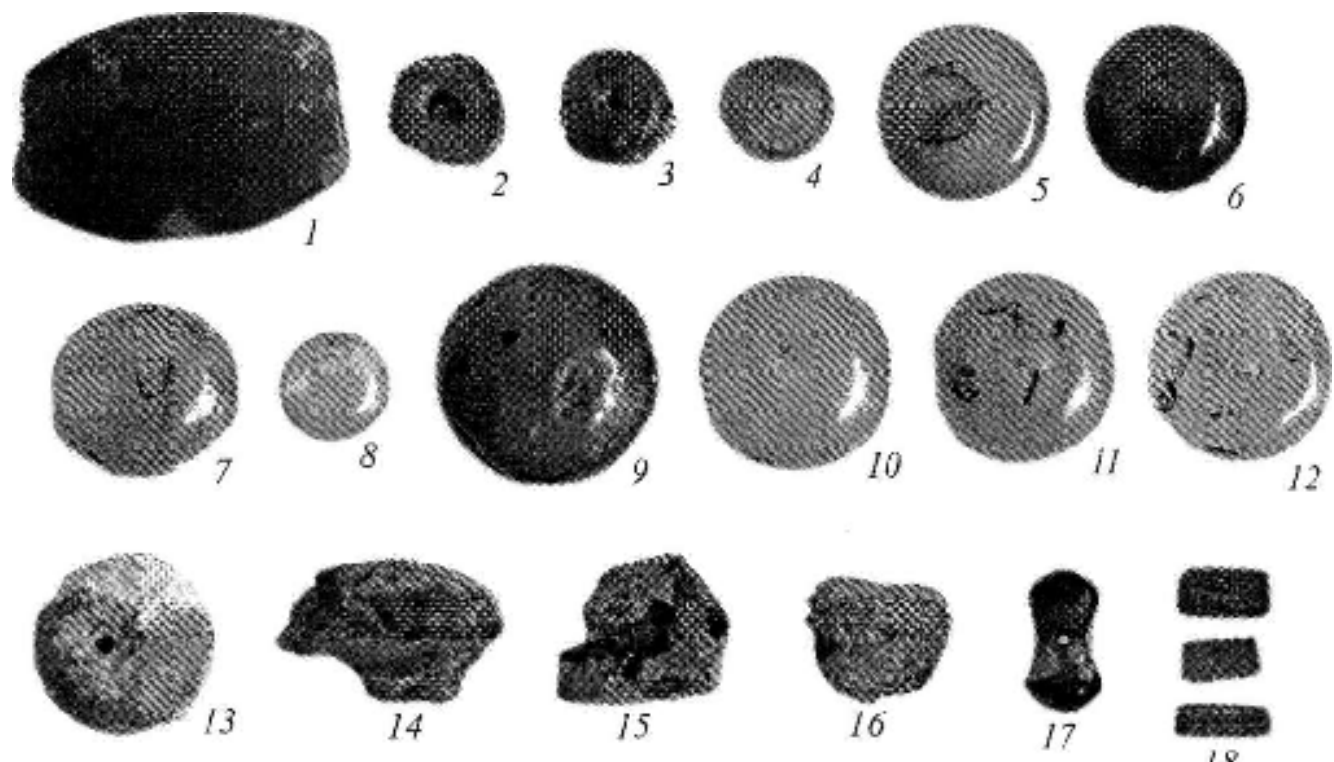

18
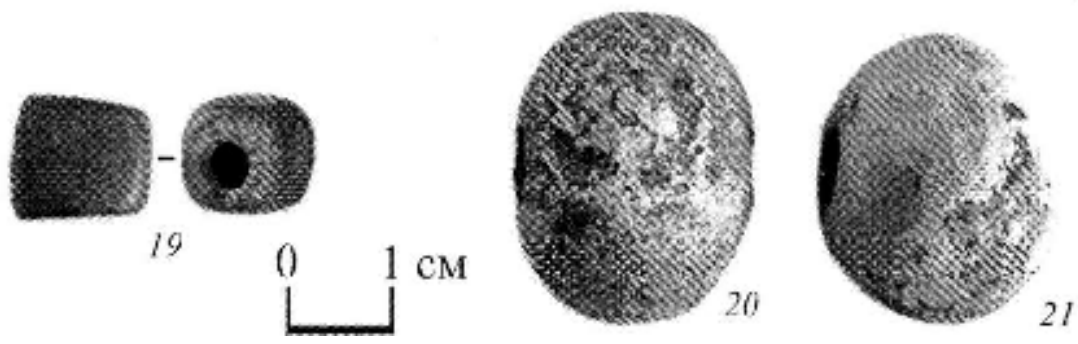

Рис. 6. Находки из окрестностей с. Алмак. Бусы из камня и металла 